\title{
Survei Tingkat Kepuasan Kerja Karyawan PT X Melalui Alat Ukur Job Satisfaction Scale
}

\author{
Mashareen, Z.C. ${ }^{1^{*}}$, Supriyanto ${ }^{1}$ dan Ivanti, A. ${ }^{1}$ \\ Program Studi Psikologi \\ Universitas Pembangunan Jaya \\ Email: oudyss@gmail.com, supriyanto@upj.ac.id, adriatik.ivanti@upj.ac.id
}

\begin{abstract}
Job satisfaction is an important factor that can increase employee performance and reduce the level of turnover in an organization. We developed the Job Satisfaction Scale to measure the employees' satisfaction at PT. $X$ through survey method. The questionnaire also enables the respondents to fill the answer quickly and easily. There were 40 employees of PT $X$ involved in this study. We conclude that $40 \%$ of employees of PT. X showed moderate job satisfaction, and $37.5 \%$ of employees of PT. X indicated low job satisfaction. In addition, the survey found that male employees above 40 years old tend to have high job satisfaction. Meanwhile, the employees who work more than one year and graduated from senior high school and higher education (Bachelor, Diploma) tend to have high job satisfaction.
\end{abstract}

Keywords : job satisfaction, job satisfaction scale, human resources

\begin{abstract}
Abstrak : Kepuasan kerja merupakan faktor penting yang dapat meningkatkan kinerja karyawan dan dapat menurunkan tingkat turnover pada sebuah organisasi. Penelitian ini ditujukan untuk menggambarkan tingkat kepuasan kerja karyawan di PT. X melalui metode survey dengan menggunakan Job Satisfaction Scale. Alat ukur Job Satisfaction Scale ini dikembangkan oleh peneliti berdasarkan kebutuhan dari PT. X Kuesioner ini juga memungkinkan subjek untuk mengisi jawaban dengan cepat dan mudah. Subjek yang digunakan dalam penelitian ini adalah 40 orang karyawan PT.X. Hasil penelitian ini menunjukkan bahwa $40 \%$ karyawan PT.X memiliki tingkat kepuasan kerja sedang, dan 37.5\% karyawan PT. $\mathrm{X}$ memiliki tingkat kepuasan kerja rendah. Selain itu, survey ini juga menemukan bahwa karyawan laki-laki yang berusia di atas 40 tahun cenderung memiliki tingkat kepuasan kerja tinggi. Sementara itu, karyawan dengan masa kerja lebih dari 1 tahun serta karyawan yang lulus dari SMA dan pendidikan tinggi (Sarjana, Diploma) cenderung memiliki tingkat kepuasan kerja yang tinggi.
\end{abstract}

Kata Kunci: kepuasan kerja, job satisfaction scale, sumber daya manusia

\section{LATAR BELAKANG}

Sumber daya manusia (SDM) merupakan aset penting dalam organisasi (Chaisunah \& Muttaqiyathun, 2011). Juniantara (2015) berpendapat produktivitas atau kinerja karyawan dapat dimaksimalkan dengan meningkatkan kepuasan kerja. Kepuasan kerja (job satisfaction) merupakan perasaan menyenangkan yang dihasilkan dari penilaian kerja atau pengalaman kerja (Lock dalam Judge \&
Saari, 2004). Davis (dalam Aziri, 2011) menjelaskan kepuasan kerja merupakan kombinasi perasaan positif atau negatif karyawan terhadap pekerjaannya.

Aamodt (2010) menjelaskan bahwa karyawan dengan tingkat kepuasan kerja tinggi cenderung berkomitmen pada organisasi, datang tepat waktu, bertahan pada organisasi, menunjukkan kinerja baik dan memunculkan perilaku positif dan bermanfaat bagi organisasi, 
dibandingkan dengan karyawan dengan tingkat kepuasan kerja rendah. Karyawan yang tidak puas dalam pekerjaannya dapat menimbulkan berbagai masalah seperti meningkatnya tingkat absensi, turnover karyawan, perilaku kerja pasif dan sebagainya (Aamodt, 2010).

Beberapa lembaga di Indonesia melakukan survei kepuasan kerja terhadap karyawan. Survei Jobstreet tahun 2014 menunjukkan bahwa 73\% karyawan tidak puas dengan pekerjaannya (Jobstreet, 2014). Survei Page (2015) pada 500 karyawan di Indonesia menunjukkan bahwa guna mempertahankan karyawan, perusahaan dapat menyusun strategi terkait dengan kepuasan kerja. Salah satu cara paling mudah mengumpulkan data tentang kepuasan kerja karyawan adalah menggunakan kuesioner (Pietersen, 2005). Pietersen (2005) menjelaskan bahwa terdapat beberapa instrumen yang dapat digunakan untuk mengukur kepuasan kerja secara valid dan reliabel atau disebut dengan existing scale atau alat ukur yang sudah ada (Spector dalam Yulianto, 2008). Contoh dari existing scale adalah Minnesota Satisfaction Questionnaire (MSQ) (Buitendach \& De Witte dalam Pietersen, 2005), Job Description Inventory (JDI) (Smith, Kendall, \& Hulin dalam Pietersen, 2005) dan Job Diagnostic Survey (JDS) (Hackman \& Oldham dalam Pietersen, 2005). Instrumen berikutnya yang dapat digunakan untuk mengukur kepuasan kerja yaitu instrumen yang dikembangkan khusus sesuai dengan karakteristik atau permintaan dari perusahaan/organisasi. Instrument jenis ini biasa disebut dengan custom made (Aamodt, 2010). Pada penelitian ini, alat ukur Job Satisfaction Scale disusun oleh peneliti sesuai dengan permintaan PT. X untuk menilai kepuasan kerja karyawannya. Menurut Yulianto (2008), custom made questionnaires memiliki kelebihan yaitu dapat mengetahui aspek-aspek yang menyebabkan ketidakpuasan serta kepuasan kerja karyawanan, karena pembuatan custom made questionnaires disesuaikan dengan tipe perusahaan dan ciri khas organisasi tersebut.

Mengingat pentingnya kepuasan kerja karyawan, hal ini mendorong PT.X melakukan survei kepuasan kerja sebagai bagian dari mengembangkan strategi untuk mempertahankan karyawan yang mampu menjaga standar tinggi yang diinginkan para pelanggan agar perusahaan tetap kompetitif dan dapat mencapai tujuan-tujuannya (Annual Report, 2014). PT.X adalah perusahaan yang bergerak di bidang konstruksi yang berdiri pada 23 Desember 1982 dan memulai kegiatan usaha komersialnya pada tahun 1982 (Rosalina, 2015). Induk usaha PT.X adalah PT. Pembangunan Jaya, dengan presentase kepemilikan saham sebesar 60,89\%. Berdasarkan Anggaran Dasar Perusahaan, ruang lingkup kegiatan PT.X berada dalam bidang pembangunan, perdagangan, perindustrian dan jasa. Saat ini PT.X bertindak sebagai pengembang, pemborong umum (general contractor), pemasangan komponen bangunan, pembangunan konstruksi segala bangunan, pemasangan instalasi, pengembangan wilayah pemukiman, pemborong pada bidang pertambangan minyak, gas dan panas bumi, pemborong bidang pertambangan umum, pemborong bidang petrokimia, pembangunan sarana dan prasarana jaringan telekomunikasi, konstruksi besi dan baja, pembangunan lapangan golf, penyelenggaraan proyek jalan tol, konstruksi sinyal dan telekomunikasi kereta api serta usaha ketenagalistrikan (Rosalina, 2015).

\section{KAJIAN LITERATUR}

Hoppock (dalam Aziri, 2011) menjelaskan bahwa job satisfaction adalah kombinasi dari aspek psikologis, fisiologis dan keadaan lingkungan yang dapat menyebabkan seseorang menyatakan bahwa 'Saya merasa puas dengan pekerjaan saya.' Kaliski (dalam 
Aziri, 2011) menjelaskan kepuasan kerja sebagai perasaan seseorang terhadap kesuksesan dan penghargaan dalam pekerjaannya, yang secara umum mempengaruhi produktivitas.

Davis \& Newstorm (dalam Aziri, 2011) menjelaskan bahwa kepuasan kerja merupakan kombinasi perasaan positif atau negatif yang dimiliki karyawan terhadap pekerjaan. Definisi kepuasan kerja menurut Locke (dalam Dugguh \& Dennis, 2014) adalah perasaan karyawan terhadap pekerjaan mereka yang mempengaruhi kinerja. Aziri (2011) menjelaskan bahwa kepuasan kerja dipengaruhi beberapa faktor seperti lingkungan kerja, gaji, kesempatan mengembangkan karir, manajemen, kelompok kerja, dan kondisi di tempat kerja. Aziri (2011) menyatakan bahwa terdapat satu teori yaitu two-factor theory yang dipopulerkan Herzberg dan digunakan dalam penelitian ini. Kemunculan two-factor theory diawali ketika Herzberg melakukan sebuah studi melalui wawancara terhadap 203 akuntan dan insinyur dari berbagai industri yang berbeda di daerah Pittsburgh, Amerika Serikat (Mullins, 2010). Herzberg menggunakan metode critical incident method yaitu meminta subjek menyebutkan kapan mereka merasa senang dan tidak senang dengan pekerjaan. Setelah itu, responden diminta memberikan alasan dan deskripsi mengenai penyebab munculnya perasaan senang ataupun tidak senang terhadap pekerjaan mereka. Kemudian, seluruh respon yang diberikan responden akhirnya disimpulkan Herzberg sebagai dua faktor berbeda yang mempengaruhi motivasi serta kepuasan kerja karyawan (Mullins, 2010). Herzberg menjelaskan bahwa kepuasan kerja terdiri dari dua kondisi yang berbeda yaitu motivatorsfactors dan hygiene factors (Dugguh \& Dennis, 2014). Dugguh \& Dennis (2014) menjelaskan bahwa motivatorsfactors adalah kepuasan kerja yang berasal dari dorongan dalam diri individu untuk mencapai tujuan pribadi dan tujuan organisasi. Motivation factors terdiri dari beberapa aspek dalam pekerjaan yang mendorong karyawan untuk menunjukkan kepuasan kerja yaitu: (1) work itself (2) achievement (3) recognition (4) responsibility (5) opportunity for advancement or promotion. Faktor berikutnya yaitu hygiene factors adalah kepuasan kerja yang berasal dari kondisi fisik dan psikologis di tempat kerja (Dugguh \& Dennis, 2014). Karyawan yang menilai dengan baik seluruh aspek hygiene factors dapat dikatakan bahwa karyawan tersebut puas dengan pekerjaannya (Furnham, 2006). Aspek-aspek dalam hygiene factors adalah: (1) supervision (2)pay (salary) (3) working conditions (4) company policies, administration and procedures (5) status (6) security (7) interpersonal relationships.

Aamodt (2010) menjelaskan konsekuensi yang dihadapi perusahaan jika banyak karyawan yang merasa tidak puas dengan pekerjaannya, yaitu: (1) absensi (2) turnover (3) perilaku yang tidak produktif (4) Lack of Organizational Citizenship Behaviors (OCBs). Herzberg (dalam Mohammed \& Eleswed, 2013) menjelaskan bahwa karyawan yang merasa puas dengan pekerjaannya akan menambahkan nilai-nilai positif bagi perusahaan. Mohammed \& Eleswed (2013) juga menjelaskan bahwa karyawan yang merasa puas akan lebih kreatif, fleksibel, inovatif dan loyal terhadap perusahaan.

\section{METODE PENELITIAN}

Desain yang digunakan dalam penelitian ini adalah kuantitatif, yaitu survei. Pada penelitian ini, desain penelitian survei yang digunakan adalah desain lintas sektoral (cross-sectional design) yaitu penelitian yang mengambil satu atau lebih sampel dari satu populasi pada saat yang bersamaan(Shaughnessy, Zechmeister \& Zechmeister, 2012). Fokus utama dari cross-sectional design adalah 
mendeskripsikan karakteristik dari suatu populasi. Berdasarkan definisi mengenai desain penelitian cross-sectional design, alasan utama peneliti menggunakan desain tersebut karena peneliti hanya mengambil sampel dari satu populasi, yaitu karyawan PT.X dan akan mendeskripsikan gambaran kepuasan kerja dari seluruh karyawan PT.X.

Karakteristik responden pada penelitian ini antara lain: (1) karyawan yang aktif bekerja di PT.X, laki-laki maupun perempuan dengan usia minimal 20 tahun (2) memiliki latar belakang pendidikan minimal SMA (3) minimal bekerja selama 3 bulan di PT.X. Semakin lama seseorang bekerja di perusahaan, maka ia akan memperoleh pengalaman lebih banyak, semakin memahami pekerjaannya dan memiliki keterampilan kerja. Di PT.X masa percobaan sebagai pegawai kontrak adalah 3 bulan, sebelum diangkat sebagai pegawai tetap di PT.X. Teknik pengambilan sampel yang dilakukan dalam penelitian ini adalah non probability sampling, dengan menggunakan teknik snowball sampling.

Alat pengumpulan data yang digunakan dalam penelitian ini adalah kuesioner. Kuesioner adalah salah satu jenis metode pengumpulan data yang disampaikan kepada responden melalui daftar pernyataan tertulis, yang dijawab secara tertulis atau memberikan tanda pada jawaban yang paling sesuai dengan keadaan atau kondisi partisipan (Craig \& Metze dalam Nugraheni, 2009). Kuesioner kepuasan kerja atau Job Satisfaction Scale dalam penelitian ini dibuat secara customized, atas permintaan PT.X kepada peneliti. Dengan membuat sendiri kuesioner diharapkan tes tersebut dapat mencakup teori mengenai kepuasan kerja secara menyeluruh. Peneliti juga dapat memastikan bahwa seluruh dimensi tercakup di dalam kuesioner. KuesionerJob Satisfaction Scale terdiri dari 60 pernyataan dan mencakup 12 aspek kepuasan kerja. Kedua belas aspek tersebut mengacu pada teori yang digunakan dalam penelitian ini. Pembuatan kuesioner berdasarkan pada teori yang dikemukakan oleh Herzberg (dalam Aziri, 2011) yang menyatakan bahwa kepuasan kerja dipengaruhi oleh dua faktor yaitu motivators dan hygiene factors (Aziri, 2011). Penjelasan dari setiap faktor dan aspek kepuasan kerja dapat dilihat melalui Tabel 1 berikut ini:

Tabel 1. Faktor dan Aspek Kepuasan Kerja

\begin{tabular}{|c|c|}
\hline \multicolumn{2}{|c|}{ Motivators Factors } \\
\hline Aspek & Penjelasan \\
\hline Work Itself & $\begin{array}{l}\text { Pekerjaan atau } \\
\text { tugas-tugas yang } \\
\text { dilakukan oleh } \\
\text { karyawan di } \\
\text { perusahaan }\end{array}$ \\
\hline Achie-vement & $\begin{array}{l}\text { Pencapaian, prestasi, } \\
\text { atau hasil-hasil yang } \\
\text { dapat dicapai } \\
\text { karyawan selama } \\
\text { bekerja }\end{array}$ \\
\hline Recog-nition & $\begin{array}{l}\text { Memberikan } \\
\text { penghargaan, } \\
\text { perhatian atau } \\
\text { catatan bagi } \\
\text { karyawan yang telah } \\
\text { menyelesaikan } \\
\text { pekerjaan dengan } \\
\text { baik }\end{array}$ \\
\hline Responsibility & $\begin{array}{l}\text { Karyawan merasa } \\
\text { memiliki tanggung } \\
\text { jawab terhadap } \\
\text { pekerjaan. }\end{array}$ \\
\hline Promotion & $\begin{array}{l}\text { Memberi } \\
\text { kesempatan pada } \\
\text { karyawan untuk } \\
\text { pindah ke posisi } \\
\text { pekerjaan yang lebih } \\
\text { tinggi. }\end{array}$ \\
\hline
\end{tabular}

Hygene Factors

\begin{tabular}{ll}
\hline Aspek & Penjelasan \\
\hline Supervision & $\begin{array}{l}\text { Kemampuan atasan di } \\
\text { perusahaan dalam memimpin }\end{array}$
\end{tabular}




\begin{tabular}{ll}
\hline & dan memperlakukan \\
Pay & karyawannya dengan adil. \\
& Perusahaan memberi gaji dan \\
& benefit sesuai, menjelaskan \\
& kebijakan mengenai gaji, \\
& kenaikan gaji, dan bonus. \\
Working & Kondisi kerja seperti suhu, \\
Conditions & cahaya, kebisingan yang \\
& tidak terlalu banyak atau \\
& sedikit yang dapat membuat \\
& karyawan merasa puas \\
& dengan pekerjaannya. \\
Policies & Kebijakan, administrasi, dan \\
proc-edures & prosedur tertentu yang dibuat \\
Status & oleh perusahaan \\
& Kedudukan sosial seseorang \\
& dalam kelompoknya yang \\
& dapat mengarah ke posisi \\
& orang tersebut dalam \\
& kelompoknya. \\
& Karyawan bebas dari \\
& ancaman pemberhentian \\
kecurity & kerja, gangguan, \\
diskriminasi, dan bullying. & Hubungan yang terjalin \\
relationship & antara manajer dengan \\
& bawahan, bawahan dengan \\
& atasan atau antar karyawan. \\
&
\end{tabular}

Kuesioner dalam penelitian ini menggunakan skala Likert yang berisi pernyataan sistematis sehingga dapat menunjukkan sikap responden terhadap pernyataan tersebut (Kholiawati, 2009). Kuesioner ini terdiri dari empat skala untuk menunjukkan tingkat persetujuan responden terhadap pernyataan yang diberikan. Skoring jawaban adalah sebagai berikut: 'sangat tidak setuju' $=1$, 'tidak setuju' $=2$, 'setuju' $=3$, dan 'sangat setuju' $=4$. Alasan dari pemilihan bentuk skala dengan pilihan jawaban genap atau satu sampai empat adalah menghindari jawaban yang cenderung mengelompok di tengah (central tendency) seperti yang biasa terjadi pada skala dengan alternatif jawaban ganjil (15 atau 1-7) (Fernandes dalam Yulianto, 2008). Alasan berikutnya dari penggunaan skala Likert dalam kuesioner ini adalah setiap item dalam kuesioner dianggap dapat menggambarkan sejauh mana faktor yang menimbulkan kepuasan atau ketidakpuasan kerja karyawan (Yulianto, 2008).

Skor total diperoleh dengan cara menjumlahkan seluruh skor dari pernyataan yang dipilih. Dengan demikian ditemukan rentang skor yaitu sebesar 60-240. Penentuan skor serta intepretasi skor dilakukan dengan menggunakan teknik z-score yang diambil dari data hasil penelitian 40 subjek. Z-score merupakan salah satu teknik perhitungan standard score yaitu mengubah skor mentah ke dalam satu skala ke skala lainnya, tergantung pada nilai rata-rata dan standar deviasi yang diperoleh (Cohen, Swerdlik, \& Sturman, 2013). Proses untuk mengubah skor mentah menjadi standard score penting untuk dilakukan karena akan memudahkan peneliti dalam mengintepretasi skor melalui standard score (Cohen, Swerdlik, \& Sturman, 2013). Hasil dari perhitungan z-score pada kuesioner kepuasan kerja dapat dilihat melalui Tabel 2 berikut ini:

Tabel 2. Hasil Perhitungan Z-Score Kuesioner Kepuasan Kerja

\begin{tabular}{|c|c|}
\hline $\begin{array}{l}\text { Rentang } \\
\text { Skor }\end{array}$ & Intepretasi Skor \\
\hline $60-149$ & $\begin{array}{l}\text { Kepuasan Kerja Sangat } \\
\text { Rendah }\end{array}$ \\
\hline $150-164$ & Kepuasan Kerja Rendah \\
\hline $165-179$ & Kepuasan Kerja Sedang \\
\hline $180-194$ & Kepuasan Kerja Tinggi \\
\hline $195-240$ & $\begin{array}{l}\text { Kepuasan Kerja Sangat } \\
\text { Tinggi }\end{array}$ \\
\hline
\end{tabular}

\section{Tahap Pengolahan Data}

Data yang telah terkumpul melalui kuesioner kemudian disaring untuk mengeliminasi responden yang tidak sesuai dengan kriteria subjek. Setelah 
menyaring data, peneliti mengolah data yang telah diperoleh melalui metode kuantitatif yang diolah dengan menggunakan Statistical Package for the Social Sciences (SPSS) versi 20. Metode statistik yang digunakan untuk mengolah data dalam penelitian ini adalah statistik deskriptif. Menurut Sevilla (dalam Kholiawati, 2009) metode deskriptif bertujuan untuk mengukur gejala-gejala yang ada tanpa menyelidiki sebab dari kemunculan gejala tersebut. Selain itu, di dalam penelitian ini peneliti tidak memperhitungkan atau melihat hubungan antar variabel dan tidak menguji hipotesis. Statistik deskriptif yang digunakan dalam penelitian ini adalah mean, median dan modus. Penggunaan dari teknik perhitungan statistik deskriptif adalah untuk mendeskripsikan atau merangkum data, selain itu teknik statistik deskriptif dapat memungkinkan peneliti untuk mendeskripsikan berbagai skor secara bermakna (Sukadji, 2000). Setelah melakukan perhitungan data melalui metode statistik deskriptif, peneliti melakukan perhitungan norma melalui teknik z-score untuk dapat mengintepretasi hasil skor yang diperoleh oleh subjek.

\section{HASIL PENELITIAN}

Berikut uraian subyek dalam penelitian ini.

Tabel 3.Gambaran Subjek Berdasarkan Karakteristik

\begin{tabular}{lll} 
Karakteristik & Frekuensi & Persentase \\
\hline Usia & & \\
$20-30$ Tahun & 31 & $78 \%$ \\
$31-40$ Tahun & 7 & $18 \%$ \\
$>40$ Tahun & 2 & $5 \%$
\end{tabular}

\section{Jenis}

Kelamin

$\begin{array}{lll}\text { Laki-Laki } & 28 & 70 \% \\ \text { Perempuan } & 12 & 30 \%\end{array}$

Jabatan

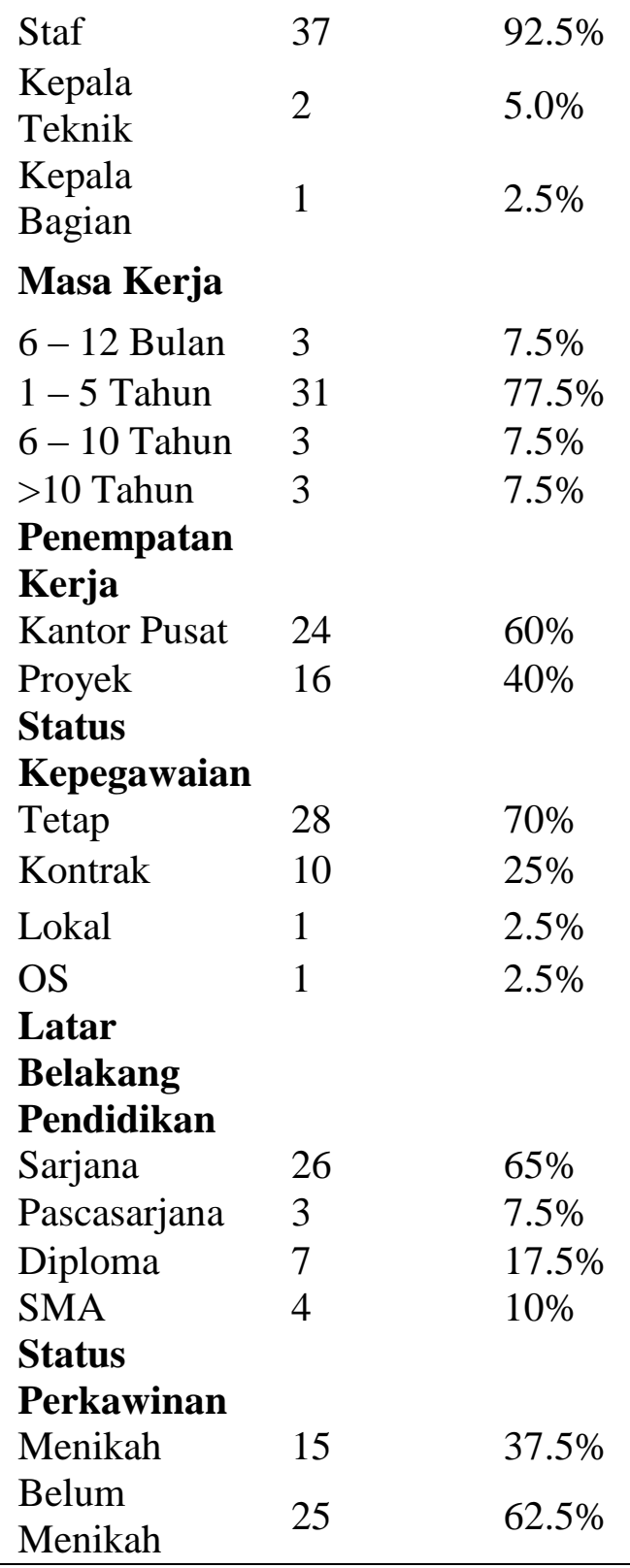

Terkait dengan gambaran kepuasan kerja, maka penelitian ini memperoleh hasil adalah sebagai berikut:

Tabel 4.Kategorisasi Skor Kepuasan Kerja

\begin{tabular}{lll} 
Kategori & Frek & \% \\
\hline $\begin{array}{l}\text { Kepuasan Kerja } \\
\text { Sangat Rendah }\end{array}$ & 4 & $10 \%$ \\
$\begin{array}{l}\text { Kepuasan Kerja } \\
\text { Rendah }\end{array}$ & 15 & $37.5 \%$ \\
$\begin{array}{l}\text { Kepuasan Kerja } \\
\text { Sedang }\end{array}$ & 16 & $40 \%$ \\
$\begin{array}{l}\text { Kepuasan Kerja } \\
\text { Tinggi }\end{array}$ & 3 & $7.5 \%$
\end{tabular}




\begin{tabular}{lll}
$\begin{array}{l}\text { Kepuasan Kerja } \\
\text { Sangat Tinggi }\end{array}$ & 2 & $5 \%$ \\
\hline Total & $\mathbf{4 0}$ & $\mathbf{1 0 0 \%}$
\end{tabular}

Tabel 4 menunjukkan perolehan skor kepuasan kerja. Hasil di atas menunjukkan bahwa $40 \%$ yaitu 16 orang memiliki tingkat kepuasan kerja sedang, $37.5 \%$ yaitu 15 orang memiliki tingkat kepuasan kerja rendah, 10\% yaitu 4 orang memiliki tingkat kepuasan kerja sangat rendah, $7.5 \%$ yaitu 3 orang memiliki tingkat kepuasan kerja tinggi, dan 5\% yaitu 2 orang memiliki tingkat kepuasan kerja sangat tinggi.

Tabel 5.Kategorisasi Skor Motivators Factors

\begin{tabular}{|c|c|c|}
\hline Kategori & Frek & $\%$ \\
\hline Kepuasan Kerja & 0 & $0 \%$ \\
\hline \multicolumn{3}{|l|}{ Sangat Rendah } \\
\hline Kepuasan Kerja Rendah & 6 & $15 \%$ \\
\hline Kepuasan Kerja Sedang & 15 & $37.5 \%$ \\
\hline Kepuasan Kerja Tinggi & 13 & $32.5 \%$ \\
\hline Kepuasan Kerja & 6 & $15 \%$ \\
\hline \multicolumn{3}{|l|}{ Sangat Tinggi } \\
\hline Total & 40 & $100 \%$ \\
\hline
\end{tabular}

Tabel 5 menunjukkan perolehan skor untuk faktor motivators factors. Hasil di atas menunjukkan bahwa $37.5 \%$ yaitu 15 orang memiliki tingkat kepuasan kerja sedang, $32.5 \%$ yaitu 15 orang memiliki tingkat kepuasan kerja tinggi. Selain itu, terdapat persentase sebesar $15 \%$ yaitu 6 orang yang memiliki tingkat kepuasan kerja rendah dan sangat tinggi. Berdasarkan dari hasil tersebut, dapat disimpulkan bahwa 37.5\% kepuasan kerja karyawan dipicu oleh dorongan dari dalam diri untuk dapat mencapai tujuan diri sendiri dan tujuan organisasi.

Tabel 6.Kategorisasi Skor Hygiene Factors

\begin{tabular}{lll} 
Kategori & Frek & \% \\
\hline $\begin{array}{l}\text { Kepuasan Kerja } \\
\text { Sangat Rendah }\end{array}$ & 1 & $2.5 \%$ \\
Kepuasan Kerja Rendah & 4 & $10 \%$ \\
Kepuasan Kerja Sedang & 13 & $32.5 \%$
\end{tabular}

\begin{tabular}{lll} 
Kepuasan Kerja Tinggi & 17 & $42.5 \%$ \\
$\begin{array}{l}\text { Kepuasan Kerja } \\
\text { Sangat Tinggi }\end{array}$ & 6 & $15 \%$ \\
\hline Total & $\mathbf{4 0}$ & $\mathbf{1 0 0 \%}$
\end{tabular}

Tabel 6 menunjukkan perolehan skor kepuasan kerja untuk faktor hygiene factors. Hasil di atas menunjukkan bahwa $42.5 \%$ yaitu 17 orang memiliki tingkat kepuasan kerja tinggi, $32.5 \%$ yaitu 13 orang memiliki tingkat kepuasan kerja sedang. Selain itu, terdapat $15 \%$ yaitu 6 orang dengan tingkat kepuasan kerja sangat tinggi, $10 \%$ yaitu 4 orang dengan tingkat kepuasan kerja rendah, dan $2.5 \%$ yaitu 1 orang dengan tingkat kepuasan kerja sangat rendah. Berdasarkan dari hasil tersebut, dapat disimpulkan bahwa $42.5 \%$ kepuasan kerja karyawan dipicu oleh lingkungan pekerjaan.

Hasil Skor Aspek Kepuasan Kerja

Tabel 7.Kategorisasi Skor Aspek Work Itself

\begin{tabular}{lll} 
Kategori & Frek & \% \\
\hline $\begin{array}{l}\text { Kepuasan Kerja } \\
\text { Sangat Rendah }\end{array}$ & 0 & $0 \%$ \\
$\begin{array}{l}\text { Kepuasan Kerja } \\
\text { Rendah }\end{array}$ & 3 & $7.5 \%$ \\
$\begin{array}{l}\text { Kepuasan Kerja } \\
\text { Sedang }\end{array}$ & 25 & $62.5 \%$ \\
$\begin{array}{l}\text { Kepuasan Kerja Tinggi } \\
\text { Kepuasan Kerja }\end{array}$ & 7 & $17.5 \%$ \\
Sangat Tinggi & 2 & $5 \%$ \\
\hline Total & $\mathbf{4 0}$ & $\mathbf{1 0 0 \%}$
\end{tabular}

Tabel 7 menunjukkan perolehan skor dari aspek work itself. Hasil diatas menunjukkan bahwa $62.5 \%$ yaitu 25 orang memiliki tingkat kepuasan sedang dan $17.5 \%$ memiliki tingkat kepuasan sangat tinggi. Selain itu, terdapat $7.5 \%$ yaitu 3 orang dengan tingkat kepuasan rendah dan $5 \%$ yaitu 2 orang dengan tingkat kepuasan sangat tinggi. Sedangkan, tidak terdapat subjek yang memiliki tingkat kepuasan sangat rendah pada aspek work itself. Berdasarkan hasil tersebut, dapat diartikan bahwa sebanyak 
62.5\% karyawan memiliki kepuasan kerja yang sedang karena kesesuaian antara tugas pekerjaan dengan kemampuan yang dimiliki.

Tabel 8. Kategorisasi Skor Achievement

\begin{tabular}{lll} 
Kategori & Frek & \% \\
\hline $\begin{array}{l}\text { Kepuasan Kerja } \\
\text { Sangat Rendah }\end{array}$ & 1 & $2.5 \%$ \\
$\begin{array}{l}\text { Kepuasan Kerja } \\
\begin{array}{l}\text { Rendah } \\
\text { Kepuasan Kerja }\end{array}\end{array}$ & 10 & $25 \%$ \\
$\begin{array}{l}\text { Sedang } \\
\text { Kepuasan Kerja Tinggi }\end{array}$ & 5 & $60 \%$ \\
$\begin{array}{l}\text { Kepuasan Kerja } \\
\text { Sangat Tinggi }\end{array}$ & 0 & $0 \%$ \\
\hline Total & $\mathbf{4 0}$ & $\mathbf{1 0 0 \%}$
\end{tabular}

Tabel 8 menunjukkan perolehan skor untuk aspek achievement. Hasil diatas menunjukkan bahwa $60 \%$ yaitu 24 orang memiliki tingkat kepuasan sedang dan $25 \%$ yaitu 10 orang memiliki tingkat kepuasan sangat rendah. Selain itu, terdapat $12.5 \%$ yaitu 5 orang dengan tingkat kepuasan tinggi dan $2.5 \%$ yaitu 1 orang dengan tingkat kepuasan sangat rendah. Sedangkan, tidak terdapat subjek yang memiliki tingkat kepuasan sangat tinggi pada aspek achievement. Berdasarkan hasil tersebut, dapat diartikan bahwa sebanyak $60 \%$ karyawan memiliki kepuasan kerja sedang karena mereka mencapai prestasi optimal sesuai dengan kemampuan.

\begin{tabular}{lll}
$\begin{array}{l}\text { Tabel 9.Kategorisasi } \\
\text { Recognition } \\
\text { Kategori }\end{array}$ & Skor & Aspek \\
\hline $\begin{array}{l}\text { Kepuasan Kerja } \\
\text { Sangat Rendah }\end{array}$ & 1 & \%rek \\
$\begin{array}{l}\text { Kepuasan Kerja } \\
\text { Rendah }\end{array}$ & 5 & $12.5 \%$ \\
$\begin{array}{l}\text { Kepuasan Kerja } \\
\text { Sedang }\end{array}$ & 15 & $37.5 \%$ \\
$\begin{array}{l}\text { Kepuasan Kerja Tinggi } \\
\text { Kepuasan Kerja Sangat } \\
\text { Tinggi }\end{array}$ & 10 & $25 \%$ \\
\hline Total & 9 & $22.5 \%$ \\
\hline & $\mathbf{4 0}$ & $\mathbf{1 0 0 \%}$
\end{tabular}

Tabel 9 menunjukkan perolehan skor untuk aspek recognition. Hasil menunjukkan bahwa $37.5 \%$ yaitu 15 orang memiliki tingkat kepuasan sedang dan $25 \%$ yaitu 10 orang memiliki tingkat kepuasan tinggi. Selain itu, terdapat $22.5 \%$ yaitu 9 orang dengan tingkat kepuasan sangat tinggi dan $12.5 \%$ yaitu 5 orang dengan tingkat kepuasan rendah. Terakhir, terdapat $2.5 \%$ atau 1 orang dengan tingkat kepuasan kerja sangat rendah. Berdasarkan hasil tersebut, dapat diartikan bahwa sebanyak $37.5 \%$ karyawan memiliki kepuasan kerja sedang karena mendapatkan pengakuan dari perusahaan ketika mereka menyelesaikan pekerjaan dengan baik.

Tabel 10.Kategorisasi Skor Aspek Responsibility

\begin{tabular}{lll} 
Kategori & Frek & \% \\
\hline $\begin{array}{l}\text { Kepuasan Kerja } \\
\text { Sangat Rendah }\end{array}$ & 1 & $2.5 \%$ \\
$\begin{array}{l}\text { Kepuasan Kerja Rendah } \\
\text { Kepuasan Kerja Sedang }\end{array}$ & 7 & $17.5 \%$ \\
$\begin{array}{l}\text { Kepuasan Kerja Tinggi } \\
\text { Kepuasan Kerja }\end{array}$ & 6 & $60 \%$ \\
$\begin{array}{l}\text { Sangat Tinggi } \\
\text { Total }\end{array}$ & 2 & $5 \%$ \\
& $\mathbf{4 0}$ & $\mathbf{1 0 0 \%}$
\end{tabular}

Tabel 10 menunjukkan perolehan skor untuk aspek responsibility. Hasil menunjukkan bahwa $60 \%$ yaitu 24 orang memiliki tingkat kepuasan sedang dan $17.5 \%$ yaitu 7 orang memiliki tingkat kepuasan rendah. Selain itu,terdapat $15 \%$ yaitu 6 orang memiliki tingkat kepuasan sangat tinggi dan 5\% yaitu 2 orang memiliki tingkat kepuasan sangat rendah. Akan tetapi, terdapat $2.5 \%$ yaitu 1 orang yang memiliki tingkat kepuasan sangat rendah. Berdasarkan hasil tersebut, dapat diartikan bahwa sebanyak $60 \%$ karyawan memiliki kepuasan kerja sedang karena diberikan kebebasan dan kekuasaan dalam bekerja, sehingga membuat karyawan merasa bertanggung jawab terhadap pekerjaannya. Akan tetapi, terdapat $2.5 \%$ karyawan yang memiliki 
kepuasan kerja sangat rendah karena tidak bertanggung jawab terhadap pekerjaannya.

Tabel 11. Kategorisasi Skor Aspek Promotion

\begin{tabular}{lll} 
Kategori & Frek & \% \\
\hline $\begin{array}{l}\text { Kepuasan Kerja } \\
\text { Sangat Rendah }\end{array}$ & 1 & $2.5 \%$ \\
$\begin{array}{l}\text { Kepuasan Kerja } \\
\text { Rendah }\end{array}$ & 9 & $22.5 \%$ \\
$\begin{array}{l}\text { Kepuasan Kerja } \\
\text { Sedang }\end{array}$ & 10 & $25 \%$ \\
$\begin{array}{l}\text { Kepuasan Kerja } \\
\text { Tinggi }\end{array}$ & 19 & $47.5 \%$ \\
$\begin{array}{l}\text { Kepuasan Kerja } \\
\text { Sangat Tinggi }\end{array}$ & 1 & $2.5 \%$ \\
\hline Total & $\mathbf{4 0}$ & $\mathbf{1 0 0 \%}$
\end{tabular}

Tabel 11 menunjukkan perolehan skor untuk aspek promotion. Hasil menunjukkan bahwa $47.5 \%$ yaitu 19 orang memiliki tingkat kepuasan tinggi dan $25 \%$ yaitu 10 orang memiliki tingkat kepuasan sedang. Selain itu, $22.5 \%$ yaitu 9 orang memiliki tingkat kepuasan rendah dan $2.5 \%$ yaitu 1 orang dengan tingkat kepuasan sangat rendah dan sangat tinggi. Berdasarkan hasil tersebut, dapat diartikan bahwa sebanyak $47.5 \%$ karyawan memiliki kepuasan kerja tinggi karena diberikan kesempatan untuk promosi jabatan atau memperoleh sertifikasi dari PT.X. Sementara itu, terdapat $2.5 \%$ karyawan yang memiliki kepuasan kerja sangat rendah karena belum diberikan kesempatan untuk promosi jabatan.

Tabel 12.Kategorisasi Skor Aspek Supervision

\begin{tabular}{lll} 
Kategori & Frek & \% \\
\hline $\begin{array}{l}\text { Kepuasan Kerja } \\
\text { Sangat Rendah }\end{array}$ & 3 & $7.5 \%$ \\
$\begin{array}{l}\text { Kepuasan Kerja } \\
\text { Rendah }\end{array}$ & 2 & $5 \%$ \\
$\begin{array}{l}\text { Kepuasan Kerja } \\
\text { Sedang }\end{array}$ & 12 & $30 \%$
\end{tabular}

\begin{tabular}{lll} 
Kepuasan Kerja Tinggi & 18 & $45 \%$ \\
$\begin{array}{l}\text { Kepuasan Kerja } \\
\text { Sangat Tinggi }\end{array}$ & 7 & $17.5 \%$ \\
\hline Total & $\mathbf{4 0}$ & $\mathbf{1 0 0 \%}$
\end{tabular}

Tabel 12 menunjukkan perolehan skor untuk aspek supervision. Hasil menunjukkan bahwa $45 \%$ yaitu 18 orang memiliki tingkat kepuasan tinggi dan 30\% yaitu 12 orang memiliki tingkat kepuasan sedang. Selain itu, terdapat $17.5 \%$ yaitu 7 orang dengan tingkat kepuasan sangat tinggi dan $7.5 \%$ yaitu 3 orang dengan tingkat kepuasan sangat rendah. Terakhir, terdapat $5 \%$ yaitu 2 orang dengan tingkat kepuasan rendah pada aspek supervision. Berdasarkan hasil tersebut, dapat diartikan bahwa sebanyak $45 \%$ karyawan memiliki kepuasan kerja tinggi karena memiliki atasan yang mampu memimpin dan memperlakukan karyawannya dengan adil. Namun, terdapat 5\% karyawan yang memiliki kepuasan kerja rendah karena memilki atasan yang tidak memiliki kemampuan memimpin dan memperlakukan karyawannya dengan adil.

Tabel 13. Kategorisasi Skor Aspek Pay

\begin{tabular}{lll} 
Kategori & Frek & \% \\
\hline Kepuasan Kerja & 2 & $5 \%$ \\
Sangat Rendah & & \\
Kepuasan Kerja Rendah & 5 & $12.5 \%$ \\
Kepuasan Kerja Sedang & 15 & $37.5 \%$ \\
$\begin{array}{l}\text { Kepuasan Kerja Tinggi } \\
\text { Kepuasan Kerja }\end{array}$ & 13 & $32.5 \%$ \\
Sangat Tinggi & 5 & $12.5 \%$ \\
\hline Total & & \\
\hline
\end{tabular}

Tabel 13 menunjukkan perolehan skor untuk aspek pay. Hasil diatas menunjukkan bahwa $37.5 \%$ yaitu 15 orang memiliki tingkat kepuasan sedang dan $32.5 \%$ yaitu 13 orang memiliki tingkat kepuasan tinggi. Selain itu, $12.5 \%$ yaitu 5 orang memiliki tingkat kepuasan rendah dan sangat tinggi. Terakhir, terdapat $5 \%$ yaitu 2 orang dengan tingkat 
kepuasan sangat rendah pada aspek pay. Berdasarkan hasil tersebut, dapat diartikan bahwa sebanyak $37.5 \%$ karyawan memiliki kepuasan kerja sedang karena perusahaan telah menetapkan kebijakan yang adil dalam memberikan kompensasi atau gaji kepada karyawannya. Namun, terdapat 5\% karyawan dengan kepuasan kerja rendah karena kebijakan perusahaan yang tidak adil mengenai kompensasi atau gaji.

\begin{tabular}{lll}
$\begin{array}{l}\text { Tabel 14.Kategorisasi } \\
\begin{array}{l}\text { Working Conditions } \\
\text { Kategori }\end{array}\end{array}$ & Skor & Aspek \\
\hline $\begin{array}{l}\text { Kepuasan Kerja } \\
\text { Sangat Rendah }\end{array}$ & 1 & \% \\
$\begin{array}{l}\text { Kepuasan Kerja Rendah } \\
\text { Kepuasan Kerja Sedang }\end{array}$ & 9 & $24.5 \%$ \\
$\begin{array}{l}\text { Kepuasan Kerja Tinggi } \\
\text { Kepuasan Kerja }\end{array}$ & 5 & $37.5 \%$ \\
Sangat Tinggi & 1 & $2.5 \%$ \\
Total & & \\
\hline & $\mathbf{4 0}$ & $\mathbf{1 0 0 \%}$
\end{tabular}

Tabel 14 menunjukkan perolehan skor untuk aspek working conditions. Hasil diatas menunjukkan bahwa $37.5 \%$ yaitu 24 orang memiliki tingkat kepuasan sedang dan $22.5 \%$ yaitu 9 orang memiliki tingkat kepuasan rendah. Selain itu $12.5 \%$ yaitu 5 orang memiliki tingkat kepuasan tinggi dan $2.5 \%$ yaitu 1 orang memiliki tingkat kepuasan sangat rendah dan sangat tinggi. Berdasarkan hasil tersebut, dapat diartikan bahwa $37.5 \%$ karyawan memiliki kepuasan kerja sedang karena perusahaan telah memberikan fasilitas kerja yang modern. Selain itu, kondisi fisik seperti ventilasi dan pencahayaan atau suhu yang terdapat di tempat kerja tidak terlalu banyak atau sedikit. Akan tetapi, masih terdapat $22.5 \%$ karyawan dengan kepuasan kerja rendah karena belum diberikan fasilitas kerja yang modern dan terlalu banyak atau sedikit ventilasi, pencahayaan, serta suhu yang terdapat di tempat kerja.
Tabel 15.Kategorisasi Skor Aspek CompanyPolicies

\begin{tabular}{lll} 
Kategori & Frek & \% \\
\hline Kepuasan Kerja & 1 & $2.5 \%$ \\
Sangat Rendah & & \\
Kepuasan Kerja Rendah & 4 & $10 \%$ \\
Kepuasan Kerja Sedang & 12 & $30 \%$ \\
Kepuasan Kerja Tinggi & 20 & $50 \%$ \\
Kepuasan Kerja & 3 & $7.5 \%$ \\
Sangat Tinggi & & \\
\hline Total & $\mathbf{4 0}$ & $\mathbf{1 0 0 \%}$
\end{tabular}

Tabel 15 menunjukkan perolehan skor untuk aspek company policies. Hasil diatas menunjukkan bahwa $50 \%$ yaitu 20 orang memiliki tingkat kepuasan tinggi dan $30 \%$ yaitu 12 orang memiliki tingkat kepuasan sedang. Selain itu,terdapat $10 \%$ yaitu 4 orang memiliki tingkat kepuasan rendah dan $7.5 \% \%$ yaitu 3 orang memiliki tingkat kepuasan sangat sangat tinggi. Terakhir, terdapat $2.5 \%$ yaitu 1 orang memiliki tingkat kepuasan sangat rendah pada aspek company policies. Berdasarkan hasil tersebut, dapat diartikan bahwa sebanyak 50\% karyawan memiliki kepuasan kerja tinggi karena perusahaan telah membuat kebijakan, aturan dan administrasi yang jelas dan diperlukan oleh karyawan. Akan tetapi, terdapat $10 \%$ karyawan dengan kepuasan kerja rendah dan $2.5 \%$ karyawan dengan kepuasan kerja sangat rendah karena kebijakan, administrasi, dan prosedur yang ditetapkan oleh perusahaan tidak jelas dan tidak diperlukan oleh karyawan PT.X.

Tabel 16.Kategorisasi Skor Aspek Status

\begin{tabular}{lll} 
Kategori & Frek & \% \\
\hline Kepuasan Kerja & 1 & $2.5 \%$ \\
Sangat Rendah & & \\
Kepuasan Kerja Rendah & 5 & $12.5 \%$ \\
Kepuasan Kerja Sedang & 10 & $25 \%$ \\
Kepuasan Kerja Tinggi & 22 & $55 \%$ \\
Kepuasan Kerja & 2 & $5 \%$ \\
Sangat Tinggi & & \\
\hline Total & $\mathbf{4 0}$ & $\mathbf{1 0 0 \%}$
\end{tabular}


Tabel 16 menunjukkan perolehan skor untuk aspek status. Hasil diatas menunjukkan bahwa 55\% yaitu 22 orang memiliki tingkat kepuasan tinggi dan 25\% yaitu 10 orang memiliki tingkat kepuasan sedang. Selain itu, $12.5 \%$ yaitu 5 orang memiliki tingkat kepuasan rendah dan $5 \% \%$ yaitu 2 orang memiliki tingkat kepuasan sangat sangat tinggi. Terakhir, terdapat $2.5 \%$ yaitu 1 orang memiliki tingkat kepuasan sangat rendah pada aspek status. Berdasarkan hasil tersebut, dapat diartikan bahwa sebanyak 55\% karyawan memiliki kepuasan kerja tinggi karena perusahaan atau atasan mereka tidak membeda-bedakan karyawan berdasarkan status atau kedudukan sosial seseorang dalam kelompoknya. Akan tetapi, terdapat $12.5 \%$ karyawan dengan kepuasan kerja rendah dan $2.5 \%$ karyawan dengan kepuasan kerja sangat rendah karena perusahaan masih membeda-bedakan karyawan berdasarkan status sosial dan ekonominya.

Tabel 17 menunjukkan perolehan skor untuk aspek security. Hasil diatas menunjukkan bahwa $47.5 \%$ yaitu 19 orang memiliki tingkat kepuasan sedang dan $37.5 \%$ yaitu 15 orang memiliki tingkat kepuasan tinggi.

\begin{tabular}{|c|c|c|}
\hline \multicolumn{3}{|l|}{$\begin{array}{l}\text { Tabel 17.Kategorisasi } \\
\text { Security }\end{array}$} \\
\hline Kategori & Frek & $\%$ \\
\hline Kepuasan Kerja & 0 & $0 \%$ \\
\hline Sangat Rendah & & \\
\hline Kepuasan Kerja Rendah & 5 & $12.5 \%$ \\
\hline Kepuasan Kerja Sedang & 19 & $47.5 \%$ \\
\hline Kepuasan Kerja Tinggi & 15 & $37.5 \%$ \\
\hline $\begin{array}{l}\text { Kepuasan Kerja Sangat } \\
\text { Tinggi }\end{array}$ & 1 & $2.5 \%$ \\
\hline Total & 40 & $100 \%$ \\
\hline
\end{tabular}

Selain itu, terdapat $12.5 \%$ yaitu 5 orang memiliki tingkat kepuasan rendah dan $2.5 \% \%$ yaitu 1 orang memiliki tingkat kepuasan sangat sangat tinggi. Sementara, tidak terdapat subjek yang memiliki tingkat kepuasan sangat rendah pada aspek security. Berdasarkan hasil tersebut, dapat diartikan bahwa $47.5 \%$ karyawan memiliki kepuasan kerja sedang karena terbebas dari ancaman pemberhentian kerja dan tidak mengalami diskriminasi dan bullying di tempat kerja. Akan tetapi, terdapat $12.5 \%$ karyawan dengan kepuasan kerja rendah karena merasa terancam dengan pemberhentian kerja atau mengalami diskriminasi dan bullying selama berada di tempat kerja.

Tabel 18 menunjukkan perolehan skor untuk aspek interpersonal relationship. Hasil diatas menunjukkan bahwa menunjukkan bahwa 55\% yaitu 22 orang memiliki tingkat kepuasan tinggi dan $22.5 \%$ yaitu 9 orang memiliki tingkat kepuasan sedang. Selain itu, $12.5 \%$ yaitu 5 orang memiliki tingkat kepuasan sangat tinggi dan $7.5 \% \%$ yaitu 3 orang memiliki tingkat kepuasan sangat rendah. Terakhir, terdapat $2.5 \%$ yaitu 1 orang memiliki tingkat kepuasan rendah pada aspek interpersonal relationship.

Tabel 18.Kategorisasi Skor Aspek Interpersonal Relationship

\begin{tabular}{lll} 
Kategori & Frek & \% \\
\hline $\begin{array}{l}\text { Kepuasan Kerja } \\
\text { Sangat Rendah }\end{array}$ & 3 & $7.5 \%$ \\
$\begin{array}{l}\text { Kepuasan Kerja Rendah } \\
\text { Kepuasan Kerja Sedang }\end{array}$ & 1 & $2.5 \%$ \\
$\begin{array}{l}\text { Kepuasan Kerja Tinggi } \\
\text { Kepuasan Kerja }\end{array}$ & 22 & $22.5 \%$ \\
Sangat Tinggi & 5 & $12.5 \%$ \\
Total & & \\
\hline & $\mathbf{4 0}$ & $\mathbf{1 0 0 \%}$
\end{tabular}

Berdasarkan hasil tersebut, dapat diartikan bahwa 55\% karyawan memiliki kepuasan kerja tinggi karena memiliki hubungan yang baik dengan rekan kerja, atasan, dan bawahannya. Akan tetapi, terdapat $7.5 \%$ dan $2.5 \%$ karyawan dengan kepuasan kerja rendah dan sangat rendah karena memiliki hubungan yang tidak baik dengan atasan, rekan kerja, dan bawahannya. 


\section{DISKUSI}

Hasil penelitian menunjukkan bahwa $40 \%$ karyawan PT.X memiliki tingkat kepuasan kerja sedang. Artinya, sebanyak 40\% karyawan merasa cukup puas dengan pekerjaannya. Tingkat kepuasan kerja karyawan PT.X yang tergolong sedang dipengaruhi oleh lingkungan pekerjaan dan kondisi psikologis di tempat kerja atau disebut dengan hygiene factors. Aspek-aspek yang terdapat dalam hygiene factors yang berpengaruh pada kepuasan kerja karyawan PT.X adalah supervision, pay, working conditions, company policies, status, security, dan interpersonal relationship.

Hasil berikutnya menunjukkan bahwa $37.5 \%$ karyawan PT.X memiliki tingkat kepuasan kerja rendah atau merasa tidak puas dengan pekerjaannya. Tingkat kepuasan kerja karyawan PT.X yang tergolong rendah dipengaruhi oleh rendahnya dorongan dari dalam diri karyawan untuk dapat mencapai tujuan diri sendiri dan tujuan organisasi, atau disebut dengan motivators factors. Aspekaspek dalam motivators factors yang berpengaruh pada rendahnya tingkat kepuasan kerja karyawan PT.X adalah achievement, recognition, dan responsibility.

\section{Kesimpulan Dan Saran}

Hasil dari perhitungan skor kepuasan kerja secara umum menunjukkan bahwa sebanyak 40\% karyawan PT.X memiliki tingkat kepuasan kerja sedang, selanjutnya sebanyak $37.5 \%$ karyawan PT.X memiliki tingkat kepuasan kerja rendah. Sedangkan, tingkat kepuasan kerja berdasarkan faktor motivators factors menunjukkan bahwa $37.5 \%$ karyawan PT.X memiliki tingkat kepuasan kerja sedang dan 15\% karyawan memiliki tingkat kepuasan kerja rendah. Berikutnya, tingkat kepuasan kerja berdasarkan faktor hygiene factors menunjukkan bahwa $42.5 \%$ karyawan PT.X memiliki tingkat kepuasan kerja tinggi dan $10 \%$ karyawan memiliki tingkat kepuasan kerja rendah.

Hasil penelitian yang telah diperoleh menunjukkan bahwa diperlukan beberapa saran untuk perbaikan penelitian ini. Pertama jumlah subjek penelitian harus diperbanyak. Kedua, kriteria subjek dibuat lebih spesifik seperti karyawan dengan masa kerja lebih dari satu tahun. Ketiga melakukan uji coba kembali terhadap item-item yang telah diperbaiki. Keempat, menyebarkan kuesioner secara langsung kepada subjek penelitian. Kelima, untuk penelitian selanjutnya variabel kepuasan kerja dapat dihubungkan dengan variabel lainnya. Keenam, menyeimbangkan jumlah item dalam kuesioner Job Satisfaction Scale.

\section{DAFTAR PUSTAKA}

1. Aamodt, M. G., 2010, Industrial/OrganizationalPsychology : An Applied Approach (6 ${ }^{\text {th }}$ ed.), United States of America: Wadsworth Cengage Learning.

2. Anastasi, A., \& Urbina, S., 1997,Psychological Testing $\left(\right.$ Ed $\left.7^{\text {th }}\right)$. New Jersey: Prentice Hall.

3. Aziri, B., 2011, Job Satisfaction: A Literature Review. Management Research And Practice, 3(4), 77-86, diperoleh dari http://mrp.ase.ro/no34/f7.pdf.

4. Burton, L. J., \& Mazerolle, S. M., 2011, Survey Instrument Validity Part I: Principles of Survey Instrument Development and Validation in Athletic Training Education Research, Athletic Training Education Journal, 6(1), 27-35, diperoleh dari http://nataej.org/6.1/0601027035.pdf.

5. Chaisunah., \& Muttaqiyatun, A., 2011, Pengaruh Kompensasi dan Lingkungan Kerja terhadap Kepuasan Karyawan: Studi Kasus pada PT. Bank Perkreditan Rakyat Shinta Daya. Jurnal Manajemen Bisnis Fokus, 1(2), 120-134, diperoleh dari 
http://manajemen.uad.ac.id/jurnal/file l.

6. Cohen, R. J., \& Swerdlik, M. E., 2010, Psychological Testing and Assesment ( $7^{\text {th }}$ ed.), New York, McGraw-Hill.

7. Cohen, R. J., Swerdlik, M. E., \& Sturman, E. D., 2013,Psychological Testing and Assesment: An Introduction to Tests and Measurement $\left(8^{\text {th }}\right.$ ed.), New York, McGraw-Hill.

8. Dugguh, S. I., \& Dennis, A., 2014, Job Satisfaction Theories: Traceability to employee performance in organizations. IOSR Journal of Business and Management (IOSR-JBM), 16(5), 11-18, diperoleh dari www.iosrjournals.org.

9. Furnham, A., 2006,The Psychology of Behaviour at Work ( $2^{\text {nd }}$ ed.), New York, Routledge Press Inc.

10. Gregory, K., 2011,The Importance of Employee Satisfaction, diperoleh dari http://www.neumann.edu/about/publi cations/NeumannBusinessReview/jou rnal/Review2011/Gregory.pdf.

11. Gregory, R. J. (2011). Tes Psikologi: Sejarah, Prinsip, dan Aplikasinya Jilid $1 \quad\left[6^{\text {th }}\right.$ Ed]. Jakarta: Penerbit Erlangga.

12. Jobstreet. (2014, November 13). $73 \%$ Karyawan Tidak Puas dengan Pekerjaan Mereka [Artikel]. Jobstreet. Diperoleh dari http://www.jobstreet.co.id/careerresources/73-karyawan-tidak-puasdengan-pekerjaan-mereka.

13. Judge, T. A., \& Saari, L. M. (2004). Employee Attitudes and Job Satisfaction. Human Resource Management, 43(4), 35-407. Diperoleh dari https://www.utm.edu/staff/mikem/do cuments/jobsatisfaction.pdf.

14. Juniantara, I. W. Pengaruh Motivasi dan Kepuasan Kerja Terhadap Kinerja Karyawan Koperasi di Denpasar. (Tesis dipublikasikan). Diperoleh dari http://www.pps.unud.ac.id/thesis/pdf thesis/unud-1227-1924960884-

tesis.pdf.

15. Kholiawati, H. (2009). Pemanfaatan Jasa Informasi Terbaru dan Terseleksi di Perpustakaan Badan Koordinasi Survei dan Pemetaan Nasional (BAKOSURTANAL). (Skripsi dipublikasikan). Diperoleh dari

http://lib.ui.ac.id/file?file=digital/127 118-RB13H134p-

Pemanfaatan\%20jasa.

16. Kumar, R. (2011). Research Methodology: a step-by-step guide for beginners ( $3^{\text {rd }}$ ed.). Washington DC: Sage Publication.

17. Mohammed. F., \& Eleswed, M. (2013). Job Satisfaction and Organizational Commitment: A Correlational Study in Bahrain. International Journal of Business, Humanities and Technology, 3(5), 43-53. Diperoleh dari http://www.ijbhtnet.com/journals/Vol 3_No_5_May 2013/6.pdf.

18. Mullins, L. J. (2010). Management \& Organisational Behaviour ( $9^{\text {th }}$ ed.). England:Pearson Education.

19. Nugraheni, I. Y. (2009). Profil Kepuasan Kerja Karyawan Departemen Operasi di Perusahaan $P Q R$. (Skripsi tidak dipublikasikan). Depok: Universitas Indonesia.

20. Page, M. (2015). 2015 EmployeeIntentions Report Indonesia. Diperoleh dari http://www.michaelpage.co.id.

21. Pietersen, C. (2005). Job Satisfaction of Hospital Nursing Staff. SA Journal of Human Resource Management,3(2), 19-25. Diperoleh dari http://sajhrm.co.za/index.php/sajhrm/ article/viewFile/66/66.

22. PT. Jaya Konstruksi MP, Tbk. (2014). Annual Report 2014. Tidak Dipublikasikan. Jakarta Selatan.

23. Rahmah. (2011). Pengaruh Sikap, Norma Subjektif, dan Percieved 
Behavioral Control (PBC) Terhadap Intensi Membeli Buku Referensi Kuliah Ilegal Pada Mahasiswa UIN Syarif Hidayatullah Jakarta. (Skripsi, Dipublikasikan). Diperoleh dari http://repository.uinjkt.ac.id>RAHM AH-FPS.

24. Rosalina, M. (2015). Pengaruh Pelatihan, Motivasi Kerja, dan Kepuasan Kerja Terhadap Kinerja Karyawan (Studi Kasus di PT. Jaya Konstruksi Manggala Pratama, Tbk). (Skripsi tidak dipublikasikan). Jakarta: Universitas Mercu Buana.

25. Saragih, K. H. (2010) Hubungan Antara Usia, Jenis Kelamin, dan Masa Kerja dengan Kepuasan Kerja Karyawan Pelaksana pada PT.Perkebunan Nusantara IV (Persero) Unit Kantor Pusat Medan. (Skripsi, Dipublikasikan). Diperoleh dari

http://repository.usu.ac.id/bitstream/1 23456789/17624/5/Chapter\%20I.pdf.

26. Shaughnessy, J. J., Zechmeister, E. B., \& Zechmeister, J. S. (2012). Metode Penelitian Dalam Psikologi [ $9^{\text {th }}$ Ed]. Jakarta: Penerbit Salemba Humanika.

27. Sido, F. (2015, Juni 25). Pekerja di Indonesia Paling Tidak Puas, Mengapa? [Artikel]. Kompasiana. Diperoleh dari http://www.kompasiana.com/afsee

28. Sukadji, S. (2000). Menyusun dan Mengevaluasi Laporan Penelitian. Salemba: Penerbit Universitas Indonesia.

29. Supriyanto. (2004). Pengambilan Keputusan Pindah Kerja (Studi Deskriptif Tentang Faktor-Faktor yang Dipertimbangkan dan Proses Pengambilan Keputusan Pada Karyawan yang Pernah Pindah Kerja). (Skripsi tidak dipublikasikan). Depok: Universitas Indonesia.

30. Tanjeen, E. (2013). A Study on Factors Affecting Job Satisfaction of Telecommunication Industries in
Bangladesh.IOSR Journal of Business and Management (IOSRJBM), 8(6) 80-86. Diperoleh dari http://iosrjournals.org/iosr-

$\mathrm{jbm} /$ papers/Vol8issue6/M0868086.pdf.

31. Yulianto, S. (2008). Rancangan Penyusunan Alat Ukur Kepuasan Kerja di PT.X. (Thesis tidak dipublikasikan). Depok: Universitas Indonesia. 